\title{
Pegagan (Centella asiatica) as a functional food for health with centelloside content
}

\author{
Noverita Sprinse Vinolina ${ }^{1 *}$ and Riswanti Sigalingging ${ }^{2}$ \\ ${ }^{1}$ Department of Agrotechnology, Faculty of Agriculture, Universitas Sumatera Utara, \\ Jln. Dr Mansyur no.9, Medan, 20222, Sumatera Utara, Indonesia \\ ${ }^{2}$ Department of Agricultural Engineering, Faculty of Agriculture, Universitas Sumatera Utara, \\ Jln. Dr Mansyur no.9, Medan, 20222, Sumatera Utara, Indonesia
}

\begin{abstract}
Pegagan or Centella asiatica is one of the wild plants that has not experienced domestication. Countries in the Eastern have been concerned about conserving medicinal plants to the sustainability of medicinal and aromatic plants. The content of secondary metabolites in Centella asiatica has been known; those are several saponin compounds, including asiaticoside, madeccasoside, and asiatic acid. This study's goal was to determine the content of secondary metabolites of asiaticoside, madeccasoside and asiatic acid at the top (leaves and petioles) and the bottom (roots and tendrils) with a harvest age of 12 weeks after planting (WAP). The planting site was in the lowlands of Deli Serdang, in which the measuring method used the HPLC tool. According to the results, Centella asiatica, harvested at 12 WAP, had a higher content of asiaticoside and madeccasoside in the roots and tendrils than in the leaves and petioles, while the content of asiatic acid was higher in the leaves and petioles than in the roots and tendrils. The bioactive compounds contained in Pegagan (Centella asiatica) are very efficacious for various diseases. Cultivation is carried out to avoid the loss of germplasm and genetic diversity in nature so that a balance in nature can be achieved.
\end{abstract}

\section{Introduction}

Back to nature is one of the focal points in human contemporary culture development in which traditional herb plants reclaim their popularity as medicinal ingredient alternatives. This current development is widely observed in developed countries and significantly impacts developing countries as the primary sources and knowledge of medicinal plants. Given the complex and organic nature of medicinal plants, the plants can then be compared to foods, substances consumed to reconstruct damaged organs or systems in the body. Back to nature has been prevalent in the West since last three decades. Meanwhile, our country starts at this millennium era, especially the upper middle classed [1].

Pegagan or Centella asiatica is one of the wild plants extensively utilized. Japanese imports medicinal and aromatic plants from China and India, where China is the major

\footnotetext{
*Corresponding author: noverita@usu.ac.id
} 
exporter of these plants [2]. The use of Pegagan (Centella asiatica) medicinal plants is very real, while the conservation efforts are very limited so that the influence is much smaller if compared to the existing needs. It occurs because of a lack of community support [3]. The Pegagan (Centella asiatica) has not experienced domestication. The chemical components of Pegagan (Centella asiatica) have been known; those are several saponin compounds, consist of asiaticoside [4]. Asiaticoside bioactive compounds can speed up the process of wound healing. Besides, the compounds are helpful to treat leprosy and tuberculosis [5-7]. Pegagan (Centella asiatica) is cool, functioning to clean the blood, improving blood circulation and nerve memory, laxative urine (diuretic), fever-reducing (antipyretic), stopping bleeding (hemostatic), antibacterial, antispasmaic, anti-inflammatory, hypotensive, insecticide, allergies, tonic, and stimulants. Saponins can also impede the extreme scar tissue production (keloids inhibit) [8].

The demand for a crude drug originated from wild plants can cause these plants to become rare and even endangered. Thus, the cultivation of these plants is necessary, in addition, to maintain uniform quality. Until now, Pegagan (Centella asiatica) still is harvested from the wild. To support the development of Pegagan (Centella asiatica) on a large scale, it is necessary to support good cultivation techniques and quality plant materials to produce quality products, both biomass production and guaranteed quality $[4,9,10]$

The demand for Pegagan (Centella asiatica) goes 100 tons/year. For PT. Sido Muncul, it goes 2-3 tons/month. Pegagan (Centella asiatica) for local needs goes 25 tons/year, yet it can only be provided about 4 tons/year. However, Pegagan (Centella asiatica) is still being hunted from the wild. Pegangan (Centella asiatica) is a plant that has not been cultivated intensively. This plant can grow in yards, gardens, or under forest stands. Some have cultivated it but have not been able to meet domestic market demand. Thus, it is time to cultivate Pegagan (Centella asiatica) because it is needed, and many herbaceous plants contain it.

The problems encountered by the Indonesian agromedicine include plants cultivation, inconsistent ingredients quality that impact the different products quality, product research and development, production processes, and marketing [11]. In agribusiness, Pegagan (Centella asiatica) can be used as a commodity that has promising prospects. It is due to positive indications for bio-business opportunities, where the demand for drugs from year to year, for domestic needs, and export to foreign countries has increased [12].

In the previous exploratory research on Pegagan (Centella asiatica) by Vinolina and Lutfi [13], the asiaticoside content of Pegagan (Centella asiatica) was obtained as follows: Deli Serdang accession (2.38\%), Kabanjahe accession (1.43\%), Medan accession (1.38\%), accession Berastagi (1.38\%), Samosir accession with shade $(0.28 \%)$.

Based on these data, the authors are interested to learn further about the effect of cultivated land conditions on the asiaticoside, madecassoside, and asitic acid contents from Pegagan (Centella asiatica). Thus, the plants' response to the conditions of the growing media by harvesting at 12 WAP to the content of secondary metabolites (asiaticoside, madecassoside, and asiatic acid) in Pegagan (Centella asiatica) can be seen.

The high demand for simplicia harvested from Pegagan (Centella asiatica) in nature without cultivating the plant will cause the plant to become rare or even endangered. Due to the demand for simplicia with uniform quality (standardized) and environmental factors, it makes the cultivation step important. The potential of Pegagan (Centella asiatica) plant material from North Sumatra is good enough to be developed. Optimization of the content of secondary metabolite in Pegagan (Centella asiatica) needs to be tested on various agronomic measures, harvest time, and different growing media. The right time for harvesting is to obtain the optimal content of asiaticoside, madecassoside, and asiatic acid, as well as Centella asiatica biomass. 
This study is expected to provide information on Pegagan (Centella asiatica) cultivation techniques with appropriate harvesting methods to produce herbal ingredients with high asiaticoside, madecassoside, and asiatic acid content, which are helpful for phytopharmaca. Besides, this study is also supposed to deliver information to the public and phytopharmaca managers regarding Pegagan (Centella asiatica).

\section{Materials and Methods}

\subsection{Place and Time}

The experiment was completed in Lubuk Pakam Deli Serdang at the height of $11 \mathrm{~m}$ above sea level from January 2020 to April 2020.

\subsection{Materials and Tools}

The materials used were Centella asiatica accession Deli Serdang, TSP, Urea, KCl, methanol and Acetonitrile for liquid chromatography, $0.3 \%$ orthophosphoric acid, asiaticoside, madecassoside, asiatic acid produced by Sigma Aldrich, aqua bidestilata sterile. Meanwhile, tools to support this research was digital scales, winnowing, plastic bags, digital camera, HPLC Shimadzu, GPS Garmin, USA, tillage equipment, meter, and others.

\subsection{Research Implementation}

The research began with soil sampling for soil chemical analysis at the Laboratory Institute for Agricultural Technology North Sumatra. It was then continued with weeds removal and soil tillage. Hereafter, 10 devised plots were made with $1 \mathrm{~m} \times 1 \mathrm{~m}$ in size with the gap of $10 \mathrm{~cm}$ between the plots. Next, liming was completed one week before planting to raise the $\mathrm{pH}$ from 5.5 to 6 based on the soil analysis results, considering the amount of dolomite to the ground was 1.5 tons/ha or $150 \mathrm{~g} / \mathrm{plot}$. The plant material used was the accessions of Deli Serdang Pegagan (Centella asiatica) seeds. The mother plants were planted for 2.5 months to form a stolen, which would be as seeds. The plant material used was stolon 1 , which has roots that have been planted in the soil to produce uniformity of seeds. The spacing used in preparing the plant material was $0.4 \mathrm{~m} \mathrm{x} 0.4 \mathrm{~m}$.

Planting was done by leaving stolon 1 in each plot while the other mother plants and stolon were dismantled. The plant population in the plot was 4 plants. Fertilization at planting was done with suitable doses of $\mathrm{P}$ treatment where the third dose of Urea and the $\mathrm{KCl}$ dose were $300 \mathrm{~kg} / \mathrm{ha}$ and $220 \mathrm{~kg} / \mathrm{ha}$, respectively. It was done by pouring fertilizer around the planting hole. Urea fertilizer was given in stages, that was at planting when the plants were 20 and 40 DAP (DAP = days after planting).

The plant maintenance was done via watering, weeding, and replanting crops. Watering was performed in the afternoon and adjusted to the field conditions. Next, stitching was finished at 2 WAP. Weeding was finished manually every day by pulling directly by hand. In this study, pests, and diseases control was conducted if any significant pests and diseases attacking plants. Finally, harvesting was conducted at 12 WAP by disassembling all plant parts.

\subsubsection{Content test of Asiaticoside, Madecassoside and Asiatic Acid}

Tests for the content levels of asiaticoside, madecassoside, and asiatic acid compounds in Pegagan (Centella asiatica) leaves were performed after harvesting to determine the 
accumulation of the compounds on the top (leaves and petiol) and bottom (roots and stolons). The content analysis of the three compounds was conducted at the laboratory of Pharmacy, USU. The procedure of analysis included: 1) Pegagan (Centella asiatica) powder was used as much as $0.2 \mathrm{~g}$, 2) Give $4 \mathrm{ml}$ of $90 \%$ methanol (90 methanol: 10 water), 3) Place them in a shaker mixing for $5 \mathrm{~h}$ (minimal time), 4) Filter via Whatman and mix with $1 \mathrm{ml}$ of $90 \%$ methanol, 5) Filter again via filter adapter $(0.45 \mu \mathrm{M}), 6)$ Save the filtrate for HPLC test, using $20 \mu \mathrm{l}$ for injections.

\section{Results and Discussion}

The results analysis of bioactive substances by HPLC in Pegagan (Centella asiatica) with harvest time of 12 WAP (weeks after planting) has been done. The content of asiaticoside (C48H78O19) in Pegagan can be seen in Table 1 and Figure 1, the content of madecassoside $(\mathrm{C} 48 \mathrm{H} 78 \mathrm{O} 20)$ in Pegagan can be seen in Table 2 and Figure 2 while content of asiatic acid $\left(\mathrm{C}_{30} \mathrm{H}_{48} \mathrm{O}_{5}\right)$ in Pegagan (Centella asiatica) in Table 3 and Figure 3.

Table 1. Content of Asiaticoside (C48H78O19) in Pegagan (Centella asiatica)

\begin{tabular}{|l|c|c|c|}
\hline Asiaticoside $(\mu \mathrm{g} / \mathrm{ml})$ & I & II & III \\
\hline Asiaticoside $(\mathrm{L})$ & 13.821 & 13.328 & 12.645 \\
\hline Asiaticoside $(\mathrm{R})$ & 17.354 & 17.385 & 16.215 \\
\hline
\end{tabular}

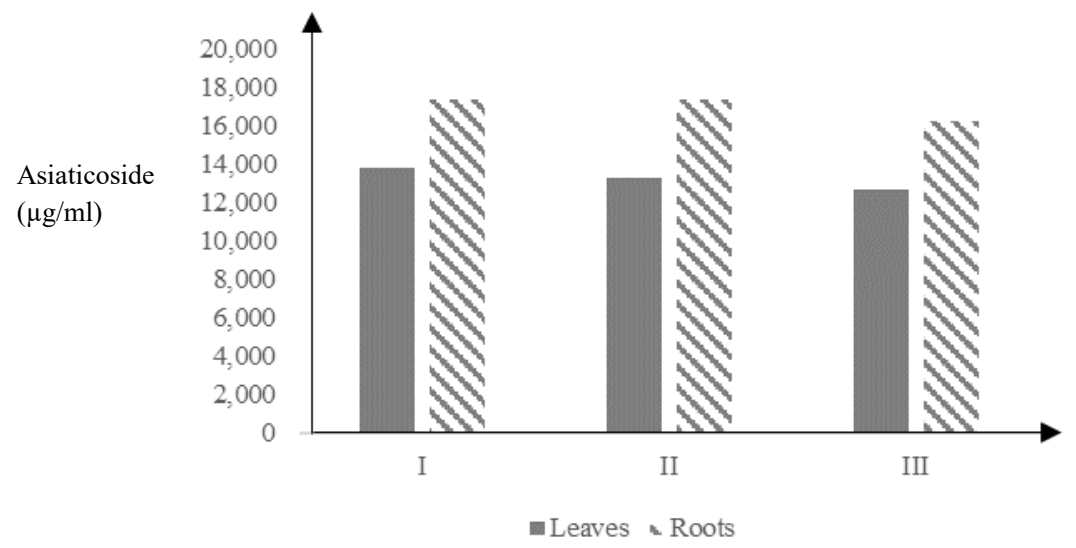

Fig.1. Content of Asiaticoside (C48H78O19) in Centella asiatica

Table 2. Content of Madecassoside (C48H78O20) in Centella asiatica

\begin{tabular}{|l|c|c|c|}
\hline Madecassoside $(\mu \mathrm{g} / \mathrm{ml})$ & I & II & III \\
\hline Madecassoside $(\mathrm{L})$ & 57.694 & 59.978 & 54.708 \\
\hline Madecassoside $(\mathrm{R})$ & 85.340 & 97.971 & 94.205 \\
\hline
\end{tabular}




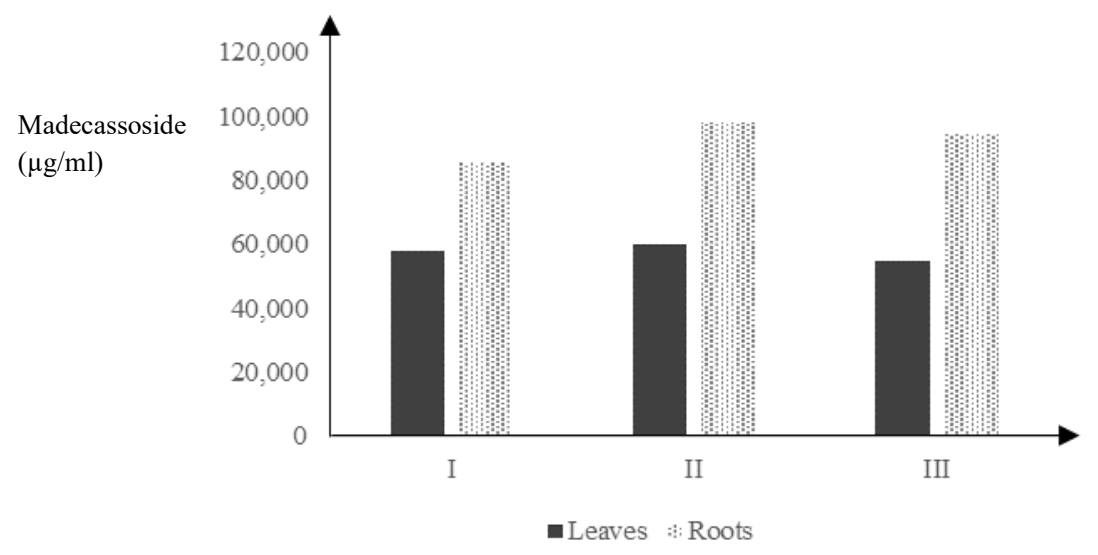

Fig.2. Content of Madecassoside (C48H78O20) in Pegagan (Centella asiatica)

Table 3. Content of Asiatic Acid $\left(\mathrm{C}_{30} \mathrm{H}_{48} \mathrm{O}_{5}\right)$ in Pegagan (Centella asiatica)

\begin{tabular}{|l|l|l|l|}
\hline Asiatic acid $(\mu \mathrm{g} / \mathrm{ml})$ & \multicolumn{1}{|c|}{ I } & \multicolumn{1}{c|}{ II } & \multicolumn{1}{c|}{ III } \\
\hline Asiatic acid $(\mathrm{L})$ & 284.190 & 260.340 & 273.350 \\
\hline Asiatic acid $(\mathrm{R})$ & 26.213 & 23.347 & 21.035 \\
\hline
\end{tabular}

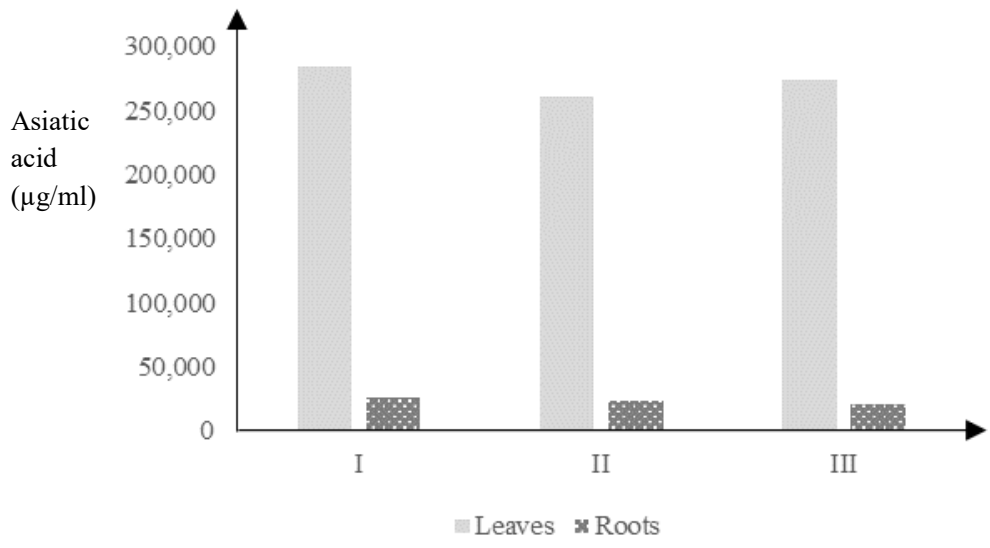

Fig.3. Content of Asiatic Acid $\left(\mathrm{C}_{30} \mathrm{H}_{48} \mathrm{O}_{5}\right)$ in Centella asiatica

Pegagan (Centella asiatica) is a wild plant that has not experienced domestication. Japan, China, Taiwan, Hong Kong, Korea, and other Eastern countries are very concerned about conserving medicinal plants [14], [15]. Japan concerns with the medicinal and aromatic plants preservation and strives to harvest medicinal plants sustainably. One of the wild plants extensively utilized is Pegagan. This study showed that leaves, roots, tendrils, and petiol contain asiaticoside, madecassoside, and asiatic acid, which are very beneficial, especially for health.

Medicinal and aromatic plants need to be cultivated for the sustainable harvesting of medicinal plants [16]. Thus, we can utilize the cultivated plants, to obtain uniform 
quality and to be able to be utilized until future generations. If it is only harvested from nature, it will cause the plants extinction, especially if it is done on a large scale because the demand is high enough. Cultivation is done to avoid loss of germplasm or genetic diversity in nature so that a balance in nature can be achieved.

The chemical constituents of Pegagan (Centella asiatica) have been known; those are several saponin compounds, consist of asiaticoside, madecassoside, and asiatic acid. Research on the secondary metabolites content in Pegagan (Centella asiatica) accession from the lowlands of Deli Serdang, on the top (leaves and petioles) and bottom (roots and tendrils) with the harvest age of 12 WAP (weeks after planting), showed that there were differences in the content level. The content of asiaticoside harvested at 12 WAP was higher in roots and tendrils (bottom) than in leaves and petioles (upper). Similarly, the content of madecassoside with the harvest of 12 WAP was higher in the roots and tendrils compared to the content in the leaves and petioles. Meanwhile, the content of asiatic acid with the harvest time of 12 WAP was higher in leaves and petioles than in roots and tendrils. The bioactive content found in Pegagan (Centella asiatica) is very efficacious for various diseases. Based on research data, it was found that Pegagan (Centella asiatica) contains very useful secondary metabolites, so it needs to be considered as a functional food for health.

\section{Conclusion}

Harvesting can be done on the top (leaves and petioles) and the bottom (roots and tendrils) because all these parts contain secondary metabolites (asiaticoside, madecassoside and asiatic acid).

The authors wish to thank the Ministry of Research, Technology and Higher Education, Indonesia for the financial support.

\section{References}

1 K. Van Nguyen, B. Pongkitwitoon, T. Pathomwichaiwat, U. Viboonjun, and S. Prathanturarug, Sci. Rep., 9, 18665, 2019.

2 A. M. Barata, F. Rocha, V. Lopes, and A. M. Carvalho, Ind. Crops Prod.,88, 8-11, 2016.

3 M. Srivastava, G. Singh, and P. Misra, Springer ,465-4862015.

4 H. Matsuda, T. Morikawa, H. Ueda, and M. Yoshikawa, Chem. Pharm. Bull.,10,13681371, 2001.

5 S. Jisha, K. N. Anith, and K. K. Sabu, Biocatal. Agric. Biotechnol.19, 2019.

6 A. Alqahtani, W. Tongkao-On, K. M. Li, V. Razmovski-Naumovski, K. Chan, and G. Q. Li, Phytochem. Anal.6,436-443, 2015.

7 O. T. Kim, M. Y. Kim, M. H. Hong, J. C. Ahn, and B. Hwang, Plant Cell Rep.5,339344, 2004.

8 S. Mangas, E. Moyano, L. Osuna, R. M. Cusido, M. Bonfill, and J. Palazón, Biotechnol. Lett.,10,1853-1859, 2008.

$9 \quad$ N. E. Gray et al.,1, 161-194. 2018.

10 N. Sprinse Vinolina, "Journal of Physics: Conference Series, 1175, 2019.

11 S. A. Aziz, M. Ghulamahdi, and A. Afrida, J. Hortik. Indones., 1, 1-5 2012.

12 B. Martono, M. Ghulamahdi, L. K. Darusman, S. A. Aziz, and N. Bermawie, J. Penelit. Tanam. Ind.,1, 12-19, 2020. 
13 N. S. Vinolina, M. Nainggolan, and R. Siregar, AGRIVITA Jour of Agri Sci ,2, 304312, 2018.

14 I. E. Orhan et al., Ind. Crops Prod., 47, 316-322, 2013.

15 I. E. Orhan, "Centella asiatica (L.) Urban: From traditional medicine to modern medicine with neuroprotective potential," Evidence-based Complementary and Alternative Medicine. 2012.

16 V. Seevaratnam, P. Banumathi, M. R. Premalatha, S. P. Sundaram, and T. Arumugam, Int J Pharm Pharm Sci. 5,8-14,2012. 